\title{
THE NECESSITY OF
}

INTERDISCIPLINARY INVESTIGATIONS

FOR PROPER UNDERSTANDING OF THE

HISTORY OF INTERNATIONAL LAW

\section{Inura Fernando*}

The heroic notion of international law as a distinct discipline is often challenged by interdisciplinary scholarship, particularly by those who are committed to highlighting the legacy of colonialism on colonised peoples. This article will highlight the entrenched formalism in international law histories. This article laments ways in which orthodox work fails to canvass histories beyond the text of the covenants and treaties that constitute international law. This article will examine key examples that highlight the importance of individual actors and sociological concepts in framing historical issues. These examples show how interdisciplinary investigations allow for a holistic understanding of the nature of international law histories. In doing so, this article aims to provide a pathway to negate the direct and indirect censorial effects of a discipline such as international law on the rendering of international law histories.

\section{INTRODUCTION}

Can accounts of the history of international law stand apart from the idiosyncrasies of the international law discipline? Can the narrative of happy normativity within orthodox international law histories survive an interdisciplinary and uncensored examination of such history? This article argues that the answer to these important questions will come as a shock to those bound to this venerable profession of International Lawyers. For a new generation of scholars, especially in the era of social media, where news does not come solely from traditional journalism, it is common sense to take an interdisciplinary approach to investigate that history. However, in many academic disciplines, there

* BHSc, LLB, LLM (Second Class Hons, First Division) in Human Rights Law (University of Auckland), Enrolled Barrister and Solicitor of the High Court of New Zealand. I want to acknowledge the unerring love and support of my parents, Mala and Lal Fernando. I want to thank Professor Dino Kritsiotis for his kind support and guidance. 
is an old guard that polices the disciplinary boundaries; and it is an unspoken rule that one dare not go beyond the rigours of one's discipline. In this respect, international law is no exception.

These questions are not mere semantics, nor the result of academic pedantry or postmodern elitism. What is at stake is a genuine problem with tangible consequences for marginalised peoples. According to Professor Susan Buck-Morss, "Disciplinary boundaries allow counterevidence to belong to someone else's story."1 Equally, Professor Martti Koskenniemi notes that the "... limits of our imagination are a product of a history that might have gone another way." ${ }^{2}$ What becomes of the venerable ideals that international law is supposed to uphold when international law as a discipline systematically ignores counter-evidence that is put forth by scholars from other disciplines? The lack of interdisciplinary approaches means foregoing the benefits of developments in other disciplines. According to Professor Koskenniemi, the history of international law is still conceived dogmatically. It is filled with binaries (such as war and peace) and grand narratives while neglecting the many developments in other fields, such as historiography, social history, international relations and genealogy. ${ }^{3}$

It is asserted that formalism is a common theme charting the history of international law. ${ }^{4}$ The formalist impulse of international law encompasses myths and assertions that the discipline takes for granted. The formalistic scholarship which charts the annals of international law posits a narrative of an international order based on sovereignty and equality of states, established in 1648 following the Peace of Westphalia. ${ }^{5}$ However, this impulse does not solely relate to myths and underlying premises. It includes the capacity to de-emphasise certain aspects of history and overemphasise others. Douglas Vick speaks of "communicative barriers" within the discipline, enshrining a status quo, which the discipline itself lacks the conceptual tools to challenge. ${ }^{6}$ Such issues of systemic inadequacy make a practical difference in the discussion of the rights of colonised peoples and the responsibilities of former colonial powers.

The tragedy of the status quo lies in the neglect of the great wealth of knowledge and understanding to be found outside the strict disciplinary boundaries. It is imperative that the international law discipline broadens its self-conception to accommodate these valuable insights. To

1 Susan Buck-Morss "Hegel and Haiti" (2000) 26 Critical Inquiry 821 at 822.

2 Martti Koskenniemi The Gentle Civilizer of Nations: The Rise and Fall of International Law 1870-1960 (Cambridge University Press, Cambridge, 2001) at 5 (emphasis added).

3 Martti Koskenniemi "Expanding Histories of International Law" (2016) 56 Am J Legal Hist 104 at 107.

4 See generally Jean d'Aspremont Formalism and the Sources of International Law: A Theory of the Ascertainment of Legal Rules (Oxford University Press, Oxford, 2011); and see also David Kennedy "Primitive Legal Scholarship" (1986) 27(1) Harv Int'1 L J 1 at 1-98.

5 Koskenniemi "Expanding Histories of International Law", above n 3, at 105-106.

6 Douglas W Vick "Interdisciplinarity and the Discipline of Law" (2004) 31(2) J L \& Soc 163 at 168. 
that end, this article draws upon the vast body of literature, on both formalism in the international law discipline and on the notions of interdisciplinarity. ${ }^{7}$ Interdisciplinary approaches to history provide a path to reflect a more authentic concept of international law and its histories. The writer who heralded the move towards interdisciplinarity across all academic disciplines is Michel Foucault. ${ }^{8}$ Foucault's work challenged the normativity of academic disciplines and life generally and explored how norms control people. ${ }^{9}$ In his 1975 classic work Discipline and Punish, ${ }^{10}$ Foucault explores a dystopian society that utilises the following methods of social control: "hierarchical observation, normalizing judgment, and the examination." ${ }^{11}$ Foucault's work on disciplinarity helps one understand what interdisciplinarity means by framing the boundaries that interdisciplinarity crosses. However, it is important that any transgressions of "disciplinary boundaries" are guided by a clear purpose and methodology. ${ }^{12}$

This article will explore the validity of the notion that proper engagement with the history of international law requires carrying out interdisciplinary investigations. First, it will outline what a proper engagement with history entails in light of the scholarship of Professor Martti Koskenniemi, Professor Hillary Charlesworth, Professor Antony Anghie and Professor Phillip Allott. Secondly, it will explore formalism in the international law discipline in light of the scholarship of Professor Koskenniemi, Sir John Fischer Williams, Captain Elbridge Colby and Professor Hugh McKinnon Wood. Thirdly, and most importantly, it will present arguments in favour of an interdisciplinary approach and discuss examples found in the scholarship of Professors Isobel Hull, Marilyn Lake Henry Reynolds, Susan Buck-Morss, Timur Kuran, John Pilger and Ileana Porras. Overall, it sets out to persuade the reader that a proper engagement with the history of international law requires an interdisciplinary investigation enabling more honest and authentic reflections of that history.

\section{SOME METHODOLOGICAL POINTS ABOUT WHAT THIS ARTICLE ADDS AND WHAT IT DOES NOT}

It is important that the reader understands the research question for this article: Does a proper understanding of the history of international law necessitate interdisciplinary investigations? This article provides a menu of examples from different disciplines and from international law that

7 See generally d'Aspremont, above n 4; see also Kennedy, above n 4, at 1-98; and Koskenniemi "Expanding Histories of International Law", above n 3, at 105-106.

8 Gary Gutting "Michel Foucault" in Edward N Zalta (ed) Stanford Encyclopedia of Philosophy (online ed, Stanford University, 2014).

9 Gutting, above n 8.

10 See Michel Foucault Discipline and Punish: The Birth of the Prison (Alan Sheridan (translator), 2nd ed, Vintage Books, New York, 1995).

11 Gutting, above $\mathrm{n} 8$.

12 Jack M Balkin "Interdisciplinarity as Colonization" (1996) 53(3) Wash \& Lee L Rev 949 at 954. 
encompass effective interdisciplinary investigations. This article underpins the idea that the history of international law is taught in a multiplicity of classrooms, not just by international lawyers or international legal historians.

This article is not about interdisciplinary investigations generally, nor is it about international law in general terms. It has a very specific focus, the history of international law, and how proper understanding of the history of international law necessitates interdisciplinary investigations. It is not a simple matter of whether interdisciplinary investigations occur in histories of international law. However, interdisciplinary investigations often occur at the fringes and are neither from the leaders in international law, nor are they performed in a systematic and deliberate manner.

This article is not about a generalised notion of challenging Eurocentric approaches to international law. However, that is a by-product of undertaking interdisciplinary investigations. It is important to understand that it is possible to challenge Eurocentric narratives of international law without undertaking interdisciplinary investigations. However, it is argued that without interdisciplinary investigations being a deliberate and conscious part of a scholars' methodology, the effectiveness of such approaches is likely to be questionable.

This article is not a generalised shopping list of what is critically wrong with the international law discipline. One such issue is the need for greater comparative international law as raised by Professors Roberts and Koskenniemi. Certainly, the reflexive needs of international lawyers are not limited to interdisciplinary investigations. Equally, Professor Roberts in her book Is International Law International? explores: ${ }^{13}$

... how different national communities of international lawyers construct their understandings of international law in ways that belie the field's claim to universality and perpetuate certain forms of difference and dominance.

Professor Roberts' work focuses on how different international lawyers from different parts of the world conceive international law. Her work, however, does not centralise interdisciplinary investigations. But, the following quote from Professor Roberts is relevant: ${ }^{14}$

International lawyers' vision of the field implicates many foundational issues, such as which areas are significant, which actors are important, which principles are fundamental, which sources are relevant, as well as which rules are settled and which are subject to change.

Before exploring the need for interdisciplinary investigations, it is important to understand the international law discipline and how it operates, and then how it relates to the history of international

13 Anthea Roberts Is International Law International? (Oxford University Press, Oxford, 2017) at 1.

14 At 2 . 
law, including how international lawyers view the world and what they consider important. This is elaborated further in the section on the formalism in histories of international law.

Some international law academics may argue that the revolution is already happening and that there is already a wealth of interdisciplinary scholarship in international law. This article is not about the lack of interdisciplinary investigations. It is important to note that interdisciplinary investigations, though present, are not seen as necessities by the predominating strands of international law approaches.

This article is also not claiming a complete lack of interdisciplinary investigations in international law scholarship. However, what is lacking is the cohesive and systematic use of interdisciplinary investigations in scholarship about the history of international law.

For example, the editors of The Oxford Handbook of the History of International Law, Professors Fassbender and Peters, provide a cogent summary of Eurocentric narratives and inequities in the histories of international law: ${ }^{15}$

The Eurocentric story of international law has proven wrong because it is incomplete. Not only does it generally ignore the violence, ruthlessness, and arrogance which accompanied the dissemination of Western rules, and the destruction of other legal cultures in which that dissemination resulted. Like most other histories, this history of international law was a history of conquerors and victors, not of the victims. Furthermore, the conventional story ignores too many other experiences and forms of legal relations between autonomous communities developed in the course of history. It even discards such extraEuropean experiences and forms which were discontinued as a result of domination and colonization by

European Powers as irrelevant to a (continuing) history of international law.

The paragraph from Professor Fassbender and Professor Peters generally captures what is wrong with international law histories. However, it does not show how interdisciplinary investigations are necessary to fully resist the Eurocentric story of international law. It lacks the necessary clear methodology to achieve this.

\section{THE VISION FOR MOVING FROM FORMALISM TO PROPER ENGAGEMENT WITH THE HISTORY OF INTERNATIONAL $L A W$}

It is important to conceptualise a new vision for the international law discipline in its treatment of its history.

15 Bardo Fassbender and Anne Peters "Introduction: Towards A Global History of International Law" in Bardo Fassbender and Anne Peters (eds) The Oxford Handbook of the History of International Law (Oxford University Press, Oxford, 2012) 1 at 2. 


\section{A Phillip Allott and the Need for a Revolution in International Law}

Phillip Allott is an Emeritus Professor of International Public Law at the University of Cambridge. ${ }^{16}$ He illuminates an even broader critique of the international law discipline in The Health of Nations. ${ }^{17} \mathrm{He}$ asserts that "[w]e must make a world-wide revolution, a revolution not in the streets but in the mind." ${ }^{18}$ As Professor Allott charts the fate of "Nowhere", ${ }^{19}$ an example of a country fraught with corruption and structural issues related to colonisation, he juxtaposes the "old regime" 20 of international law, symbolised by its systemic formalism, with the "new view of the human world and its law"21 that he proposes. In this system "[i]nternational law is the law of international society, the true law of a true society." 22 His idyllic system is one in which all people and all states in the international society partake in the creation of international law. ${ }^{23}$ His new system begets the question: What are the power dynamics that underlie the old system and how can they be changed ${ }^{24}$ In conceiving of international law in this way, Professor Allott anchors the importance of everyday people being in dialogue with international law. His work highlights the importance of empathy. It illustrates that proper engagement with history is interlinked with questions of empathy with a broader audience than international law traditionally engages with. This, in turn, highlights the creative potential of a wide gamut of disciplines in meeting these needs.

\section{B Martti Koskenniemi and Changing the Self-Definition of International Law}

It is important to understand that the definition of international law affects questions of proper engagement with its history; formalist definitions of international law thus engender formalist histories. The works of Professor of International Law, Martti Koskenniemi from the University of Helsinki, illustrate the importance of changing the self-definition of international law. ${ }^{25}$ There is a

16 "Prof. Phillip Allott" (2016) Trinity College Cambridge <trin-hosts.trin.cam.ac.uk>.

17 Phillip Allott The Health of Nations: Society and Law Beyond the State (Cambridge University Press, Cambridge, 2002) [The Health of Nations]; see also Phillip Allott Eunomia: New Order for New World (Oxford University Press, Oxford, 1991); and Karen Knop "Eunomia is a Woman: Philip Allott and Feminism" (2005) 16 EJIL 315.

18 The Health of Nations, above n 17, at 400.

19 At 400 .

20 At 418

21 At 420

22 At 420

23 At 420

24 At 421

25 "Martti Koskenniemi" University of Helsinki <www.helsinki.fi>. 
unique genealogy to his work; his famous book on the history of international law, The Gentle Civilizer of Nations, ${ }^{26}$ complements his earlier book on the structure of international law arguments, From Apology to Utopia, ${ }^{27}$ which outlines the definitional underpinnings of international law. The Gentle Civilizer of Nations highlights the failure of the international law discipline over the last four decades to harness its creativity and canvass issues outside the straitjacket of academic, pragmatic and internationalist visions of international law. ${ }^{28}$ In particular, Professor Koskenniemi explored the "argumentative practice ... of the transformational rules that underlay international law as a discourse". ${ }^{29}$ It exposed the tendency of international law to conceptualise itself into binary relationships. ${ }^{30}$ In The Gentle Civilizer of Nations, Professor Koskenniemi challenges some of the myths relating to the origins of modern international law and poses a significant methodological challenge to international lawyers exploring the history of the profession. ${ }^{31}$ Professor Koskenniemi concludes that the "[r]eturn to 'gentle civilizing' as a professional self-definition is certainly no longer plausible." 32

\section{Antony Anghie and Postcolonial Imperatives}

Some have argued that a decolonised conception of the truth is the quid pro quo of the grand universalist narratives of international law. ${ }^{33}$ Antony Anghie, Professor at the National University of Singapore, ${ }^{34}$ has made a standout contribution to the field of Third World Approaches to International Law (TWAIL) and his classic work Imperialism, Sovereignty and the Making of International Law is relevant for this article's discussion. ${ }^{35}$ This work by Professor Anghie belies the hard truth of international law as a discipline, one that is underpinned by a continuing motif, which is the colonial

26 Koskenniemi The Gentle Civilizer of Nations: The Rise and Fall of International Law 1870-1960, above n 2 , at 1 .

27 Martti Koskenniemi From Apology to Utopia: The Structure of International Legal Argument (Lakimiesliiton kustannus, Helsinki, 1989).

28 Koskenniemi From Apology to Utopia: The Structure of International Legal Argument, above n 27.

29 Koskenniemi The Gentle Civilizer of Nations: The Rise and Fall of International Law 1870-1960, above n 2, at 1 .

30 At 1.

31 At 4 .

32 At 5 .

33 See generally Anne Orford (ed) International Law and its Others (Cambridge University Press, Cambridge, 2006).

34 "Antony Anghie" (2020) National University of Singapore <law.nus.edu.sg $>$.

35 Antony Anghie Imperialism, Sovereignty and the Making of International Law (Cambridge University Press, Cambridge, 2005). 
power relationship between Europe and her subaltern counterpart, the non-Europe. ${ }^{36}$ The mainstay of this motif is the doctrine of sovereignty, which according to Professor Anghie, was conceptualised by colonialists as an attempt to provide a legal framework to the colonial endeavour. ${ }^{37}$ Professor Anghie outlines the raison d'etre of his book as the following: ${ }^{38}$

I seek to challenge conventional histories of the discipline which present colonialism as peripheral, an unfortunate episode that has long since been overcome by the heroic initiatives of decolonization that resulted in the emergence of colonial societies as independent, sovereign states.

His work builds on a genealogy of postcolonial scholarship ${ }^{39}$ ranging from Edward Said, ${ }^{40}$ Gayatri Chakravorty Spivak ${ }^{41}$ and Homi Bhabha. ${ }^{42}$ His work is pivotal in exposing the ardent normative impulse of international law and its histories: to exclude and conceal power relations.

Professor Anghie asserts that much of the scholarship that followed the colonial period nonetheless maintained the "basic dichotomy between the civilized and uncivilized". ${ }^{43}$ For example, his assessment of Francisco de Vitoria's De Indis Noviter Inventis is different from that of the mainstream which regards it as the "first international law text". ${ }^{4}$ Professor Anghie exposes the colonialist bias in Vitoria's natural law reasoning on the topic of the conquest of the Indies by the Spanish. ${ }^{45}$ Professor Anghie asserts that Vitoria uses racism to justify the colonisation of the Indies by the Spanish through the rubric of natural law. ${ }^{46}$ The crux of the matter is that Vitoria conceived the indigenous population of the Indies as an uncivilised people and hence without the legal capacity afforded to so-called civilised people. ${ }^{47}$ Vitoria goes on to sketch a path based on doctrines of natural

36 At 3 .

37 At 3 .

38 At 3 .

39 At 9 .

40 See generally Edward Said Orientalism (Pantheon Books, New York, 1978); and Edward Said Culture and Imperialism (Alfred A Knopf, New York, 1993).

41 See generally Djelal Kadir A Critique of Postcolonial Reason: Toward a History of the Vanishing Point (Harvard University Press, Cambridge (Mass), 1999).

42 See generally Homi Bhabha The Location of Culture (2nd ed, Routledge, London, 2012).

43 Anghie, above n 35, at 4.

44 At 9 .

45 At 9 .

46 At 9 .

47 At 9 
law to show how the actions of Spain in conquering the Indies was justified in the interests of converting the indigenous peoples to a civilised way of life. ${ }^{48}$

The proper engagement with the history of international law should therefore not replicate the colonial dichotomies that Professor Anghie explores in his writings. Instead, proper engagement involves a process of unravelling the true colonial roots of international law doctrines and agreements.

\section{Hilary Charlesworth and International Law's Focus on Crisis}

The proper engagement with the history of international law entails a holistic understanding of issues that are not clouded by a special focus on a particular phenomenon at the expense of others. Hilary Charlesworth has made a noteworthy contribution to this field as a Professor of International Law and Human Rights at Australia National University. ${ }^{49}$ Professor Charlesworth's work complements the work of Professor Anghie in challenging colonial power imbalances in scholarship. In her article "International Law: A Discipline of Crisis", ${ }^{50}$ she uses the Kosovo crisis to illustrate that international law's tendency to centralise crises comes at a cost: what is left out of the conversation on crises. ${ }^{51}$ The consequent narrative is unhelpful and limited in terms of answering a broader range of central questions. ${ }^{52}$ She quips that the focus on crises "shackles international law to a static and unproductive rhetoric." 53 Her critique cuts to the core of the legal method in the international law field. She asserts that "[w]e have a penchant for cutting crises down to bite-size pieces." 54 In this process, even though it would seem a natural inclination of the international legal discipline to focus on material facts as opposed to focuses borne out of guiding concepts in another discipline, ${ }^{55}$ it nonetheless means the exclusion of concepts from other disciplines whether or not these concepts were, in fact, irrelevant in the broader scheme of things. Professor Charlesworth shows how this results in allowing crises to frame the conception of the international law discipline, rather than providing a guiding motif, at the forefront of the advancement of the discipline. ${ }^{56}$ Professor Charlesworth comments that the discipline is "technically limited because it rests on truncated and

\footnotetext{
48 At 9 .

49 "Professor Hillary Charlesworth" (2016) Australia National University <researchers.anu.edu.au>.

50 Hilary Charlesworth "International Law: A Discipline of Crisis" (2002) 65 MLR 377 at 377.

51 At 377; and see also Michael Reisman and Andrew Willard (eds) International Incidents: The Law That Counts in World Politics (Princeton University Press, Princeton, 1988).

52 Charlesworth, above n 50, at 377.

53 At 377.

54 At 384.

55 At 383

56 At 382.
} 
selective understandings of events; it also diverts attention from the structural issues of global justice. ${ }^{" 57}$ She opines that: ${ }^{.8}$

Our discipline does not encourage the weighing up of competing versions of events. What we glean then

as 'facts' may be inaccurate or partial, and the way we report and emphasise them is an act of political interpretation. We do not acknowledge this in the way we write.

Professor Charlesworth critiques what she terms "The heroic mission of international lawyers". ${ }^{59}$ She laments that "[i]nternational law becomes the voice of civilisation, of universal humanism against underdeveloped, squabbling, rest of the world." ${ }^{60}$ Yet, the conventional methodology of international law neglects structural issues such as gender-based discrimination and gender-based violence which do not neatly fall in the rubric of crises. ${ }^{61}$ She concludes by emphasising the importance of "... an international law of everyday life" that would have the epistemic capacity to consider the life experiences of marginalised groups. ${ }^{62}$ Ultimately, her work highlights the importance of a holistic understanding of issues when factoring in what constitutes a proper engagement with history.

\title{
IV THE FUTURE BEHIND US: FORMALISM AND THE HISTORY OF INTERNATIONAL LAW
}

To heal the damaging effects of formalist histories, these histories must first be identified. The orthodox histories of international law reveal a default setting that includes some perspectives and events, while excluding others. The following present the most important of such characteristics.

\section{A Sovereignty and State Centrism in International Law Histories}

Professor Koskenniemi critiques international lawyers' preoccupation with sovereignty, noting that despite awareness of the need to question formalist approaches, sovereignty nonetheless forms an organising principle for scholarship on the history of international law. ${ }^{63}$ This naturally means that any critique of the history of international law also focuses on notions of sovereignty. ${ }^{64}$ Professor Koskenniemi notes that the focus of the discipline has been dominated by intergovernmental issues and has wholly ignored "private law relations that undergird and support state action that becomes

\author{
57 At 382 . \\ 58 At 384 \\ 59 At 387 \\ 60 At 388 \\ 61 At 389 . \\ 62 At 391 \\ 63 Koskenniemi "Expanding Histories of International Law", above n 3, at 109. \\ 64 At 110.
}


visible only once analysis penetrates beyond the official statements or formal acts of governments and diplomatic chancelleries." 65 Professor Koskenniemi explores subtle examples of formalist histories in international law. These include works that heighten the importance of writings by Niccolò Machiavelli and Thomas Hobbes, while ignoring the work of Antoine de Montchrétien and Adam Smith. ${ }^{66}$ Orthodox histories also place a great emphasis on Spain's colonisation of the Indies and yet fail to study in any great depth the importance of the extraction of silver from Bolivia to the Spanish colonial economy. ${ }^{67}$ They place immense emphasis on what Hugo Grotius deemed just war yet ignore a crucial detail in their assessment of his views, namely, his tendency to justify the Dutch colonial project. ${ }^{68}$ In particular, Grotius considered the Dutch East Company to have a dual capacity, on the one hand as a commercial enterprise and on the other hand as a symbolic extension of the Dutch state. ${ }^{69}$ A further example pertains to histories that devote attention to Emer de Vattel's Droit des gens, while ignoring jurists such as Christian Thomasius and his contemporaries who were of the view that ius gentium was not iustum or honestum but merely the decorum of diplomacy. ${ }^{70}$

Professor Koskenniemi's work highlights the complicated nature of international law. Therefore, proper engagement with the history of international law requires an approach that can embrace this complexity. Furthermore, it would be a disservice to shy away from this complexity. These more subtle examples require those from the former colonial powers, and thus the inheritors of colonial privilege, to ask the uncomfortable questions of their forebears. These examples are also symptomatic of pervading "State-centrism"71 in international law histories. Professor Koskenniemi conveys the multidimensional nature of the current state of international law when he asserts that "[i]nternational law is ... [the] terrain of fear and ambition, fantasy and desire, conflict and utopia, and a host of other aspects of the phenomenological lives of its practitioners." 72

\section{$B$ Ignoring the Importance of Individual Actors}

A key marker of formalist histories is that they ignore the importance of individual actors. The work of Sir John Fischer Williams exemplifies this. Sir John Fischer Williams was an important international lawyer of the early twentieth century involved in the workings of international law

65 At 109 .

66 At 108

67 At 108 .

68 At 108

69 At 108 .

70 At $108-109$.

71 At 107

72 Koskenniemi The Gentle Civilizer of Nations: The Rise and Fall of International Law 1870-1960, above $\mathrm{n} 2$, at 7 . 
organisations and major conferences in Paris and The Hague. ${ }^{73}$ In his work Some Aspects of the Covenant of the League of Nations ${ }^{74}$ he displays aspects of formalism in the discipline. This is despite biographers noting that "[a]ll his work combined the clearness and the realism of a first-class legal mind with the forward-looking outlook of the idealist". ${ }^{75}$ To an extent, he does try to carry his writing without what he calls "the distractions of a knowledge of contemporary history". ${ }^{76}$ However, the focus of his work is very much based on a state-centric vision of how the covenant came about. ${ }^{77}$ From the perspective of the uncensored historian, in Sir John Fischer Williams' chapter on minorities and mandates ${ }^{78}$ ( 25 pages out of the 300-page book), there is only one page that even mentions Japan's proposal for racial equality for the League of Nations. ${ }^{79}$ Even then, only a very mechanical description is present, lacking any mention of interrelationships with the diplomatic actors from various nations (such as Australia, New Zealand, Britain, Japan, China and South Africa) and how this contributed to the defeat of the Japanese proposal. ${ }^{80}$ Equally, the work of Alfred Zimmern, Professor of International Relations ${ }^{81}$ at New College, Oxford is relevant. In his most famous work, ${ }^{82}$ The League of Nations and the Rule of Law 1918-1935, ${ }^{83}$ he does not mention the Japanese proposal for racial equality at all. Biographers, however, were more critical of him, noting his work was "flawed through being time-bound, dominated by the events and spirit of its day." 84

73 JL Brierly "Williams, Sir John Fischer (1870-1947)" in Oxford Dictionary of National Biography (online ed, Oxford University Press, 2008).

74 John Fischer Williams Some Aspects of the Covenant of the League of Nations (Oxford University Press, London, 1934).

75 Brierly, above $\mathrm{n} 73$.

76 John Fischer Williams, above n 74, at 1.

77 Koskenniemi "Expanding Histories of International Law", above n 3, at 107.

78 John Fischer Williams, above n 74, at 186-211.

79 At 191.

80 See generally Marilyn Lake and Henry Reynolds Drawing the Global Colour Line: White Men's Countries and the International Challenge of Racial Equality (Cambridge University Press, Cambridge, 2011) at 284309 .

81 DJ Markwell "Zimmern, Sir Alfred Eckhard (1879-1957)" in Oxford Dictionary of National Biography (online ed, Oxford University Press, 2004).

82 Markwell, above n 81.

83 See generally Alfred Zimmern The League of Nations and the Rule of Law 1918-1935 (Macmillan and Co, London, 1936).

84 Markwell, above n 81. 


\section{Reinforcing Racist Colonial Binaries and Eurocentric Mythologies}

Another key feature of formalist histories is their reinforcement of colonial binaries and Eurocentric mythologies. The article written by the Captain of the United States Army, Elbridge Colby, in the prestigious American Journal of International Law entitled "How to Fight Savage Tribes" 85 exposes something far beyond formalism in the discipline: avid racism. ${ }^{86}$ Colby's article explores a quote from Professor Quincy Wright regarding the Damascus bombardment, and in particular, whether there should be a distinction in the international laws of war between so-called civilised and uncivilised peoples. ${ }^{87}$ Colby argues that a "distinction is existent" ${ }^{88}$ His rationale for this thesis is based on so-called differences between what he deems "savage or semi-savage peoples", and non-savage (meaning Europeans from the West) in the manner of conducting war. ${ }^{89}$ According to Colby, when wars between these two groups occur, army commanders from the West have no way of differentiating between combatants and non-combatants in the so-called savage group. Therefore, the Western armies are at risk when the so-called savages use this fact to their advantage and carry out guerrilla-style attacks on the Western armies, who often get caught off guard. ${ }^{90}$ Therefore, Colby concludes that it is imperative that the modus operandi of Western armies and laws of war that apply to them, when fighting so-called savage tribes, is different from that which applies when fighting socalled civilised (Western) armies. ${ }^{91}$

Colby is not an international lawyer, but it is not as if his sentiments ran completely in the face of the history of international law. There is a brutal honesty to his work. He outlines the racist/Eurocentric and non-universalist underpinnings of international law that had been lost or deemphasised in later grand narratives about universal human rights. His work also contains some myths about international law that have been refuted by interdisciplinary scholarship. ${ }^{92}$ An example of such a myth espoused by Colby is that international law had its roots in Christianity, and that when scholars such as Grotius and Vattel were formulating the laws of war, they were extending concepts they

85 Elbridge Colby "How to Fight Savage Tribes" (1927) 21(2) AJIL 279.

86 See also Robert A Williams Savage Anxieties: The Invention of Western Civilization (Palgrave Macmillan, New York, 2012).

87 Colby, above n 85, at 279.

88 At 279 .

89 At 279

90 At 279

91 At 279 .

92 See generally Frédéric Mégret "From 'Savages' to 'Unlawful Combatants': A Postcolonial Look at International Humanitarian Law's 'Other'" in Anne Orford (ed) International Law and its Others (Cambridge University Press, Cambridge, 2006) 265 at 265-317. 
borrowed from Christianity. ${ }^{93}$ In effect, Colby's work showcases the colonial mindset that postcolonial scholars, such as Professor Anghie, seek to challenge.

Equally, Professor Hugh McKinnon Wood's 1943 article in the American Journal of International Law entitled "The Treaty of Paris and Turkey's Status in International Law"94 is worthy of discussion. It showcases elements of formalist histories and repeats the myth that international law arose in the West, was accentuated by Christian precepts and that international law was immaterial for countries outside the West. ${ }^{95}$ It ignores the importance of the Ottoman capitulations that predate the 16th century ${ }^{96}$ which had an indelible impact on the development and origins of international law "in its present form". ${ }^{97}$ Their scant mention of Ottoman capitulations does not capture their true essence. It states: ${ }^{98}$

The time was ripe for recognizing those relations to be governed by international law instead of the ambiguous combination of treaties and of compromise between Christian and Turkish practice to which lawyers had been forced to resort for their legal interpretation.

At worst, this work has erased the Ottoman capitulations out of the history of international law, and at best, has ignored their significance for the origins of international law. Thus, a more robust scholarship is needed to fully explore the extent to which international law as a system of law arose outside of the West. This will finally put to rest any qualms about whether the non-Western world did play a significant role in shaping international law.

\section{Looking Forward: Interdisciplinary Approaches in Action}

Despite hesitations and some institutional pushback, international lawyers and other professionals in different disciplines have successfully incorporated interdisciplinary investigations in their work. The following are salient examples that pertain to the history of international law.

\section{History}

(a) Isabel V Hull and diaries of Prussian military officers

93 Colby, above $\mathrm{n} 85$, at 280 .

94 Hugh McKinnon Wood "The Treaty of Paris and Turkey's Status in International Law" (1943) 37(2) AJIL 262.

95 At 262 .

96 See generally Timur Kuran The Long Divergence: How Islamic Law Held Back the Middle East (Princeton University Press, Princeton, 2011) at 209-227.

97 Wood, above n 94, at 262.

98 At 272 . 
Isabel V Hull is a Professor of History at Cornell University. ${ }^{99}$ Professor Hull's book, Absolute Destruction: Military Culture and the Practices of War in Imperial Germany, ${ }^{100}$ is a testament to the value of interdisciplinary investigations. Hull has gone beyond the orthodoxies of the historical discipline using interdisciplinary investigations and has allowed greater scope for critical engagement. For international lawyers, it provides an opportunity to go beyond the focus on crises and legal fact patterns to a more subtle, nuanced understanding of the processes of violence. It explores the individual actors and the collective mindset which underpinned the genocide of the Herero and Nama people by the German military in German Southwest Africa (present-day Namibia). ${ }^{101}$

Professor Hull initially poses some pertinent questions to consider: ${ }^{102}$

Was the extermination of the Herero planned, and if so by whom? Was it policy from Berlin, from the Kaiser, or from the General Staff? Was it intended from the beginning by the commander, Lt. Gen. Lothar von Trotha, a natural product of his racism? Was it inherent in colonial dynamics? Or did it, as I think, develop from military-institutional culture as this unfolded in an unsuccessful and difficult war?

Professor Hull ventures into the fields of sociology and political theory, particularly highlighting scholarship on the institutional nature of violence, to unify and navigate her historical argument. She borrows heavily from the works of Hannah Arendt ${ }^{103}$ and Barry Turner. ${ }^{104}$ In borrowing from Hannah Arendt's notion that "the danger of violence, even if it moves consciously within a nonextremist framework of short-term goals, will always be that the means overwhelm the end", ${ }^{105}$ Professor Hull can go beyond the simplistic causal explanations that underpin the conventional methods of historical research and analysis to "ask what impels organizations, groups, or leaders to use excessive violence, and they often find the answers in ideology (like racism or imperialism ...)."106 Professor Hull outlines a more nuanced picture following Weberian theory. ${ }^{107}$ She argues that the

99 "Isabel Virginia Hull" (2016) Cornell University <history.cornell.edu>.

100 Isabel V Hull Absolute Destruction: Military Culture and the Practices of War in Imperial Germany (Cornell University Press, New York, 2005).

101 At 5 .

102 At 5 .

103 Hull, above n 100, at 324; see also Hannah Arendt On Violence (Houghton Mifflin Harcourt Publishing Co, New York, 1970) [On Violence]; Hannah Arendt Eichmann in Jerusalem: A Report on the Banality of Evil (The Viking Press, New York, 1963); and Hannah Arendt The Origins of Totalitarianism (New ed, Harcourt, Brace \& World, New York, 1966).

104 Hull, above n 100, at 3; and see also Barry A Turner "The Organizational and Interorganizational Development of Disasters" (1976) 21(3) A S Q 378 at 395.

105 On Violence, above n 103, at 80.

106 Hull, above n 100, at 324.

107 At 324 (emphasis added). 
genocide of the Herero and Nama peoples by the German military illustrates that "[e]ven a defined (and therefore limited) goal - of crushing a revolt, for example - can be enough to trigger a procedural dynamic ending in genocide." 108 The violent culture and habits of the institution, that is the army, meant that "rationality of extreme actions develops from the means, not from the original end or goal." 109

There is a parallel here with the earlier critique of the simplistic and racist binary habit of labelling some armies savage and others non-savage in Colby's formalist work. Equally, sociologist Barry Turner's notion that "[s]mall-scale failures can be produced very rapidly, but large-scale failures can only be produced if time and resources are devoted to them", ${ }^{110}$ has helped Professor Hull frame her methodology. She utilises Barry Turner's scholarship on "organizational-cultural analysis" to conclude "that in Germany's military culture a great deal of time and resources had indeed been devoted to produce institutional failure this large and this repetitive."111

Professor Hull draws on a range of primary sources in her work and in doing so, she shows how international law can benefit from a practical grasp of history in all its complexity. Unlike the muses of formalist international lawyers, such as the text of covenants, case law and theory, she furnishes her work with maps, ${ }^{112}$ photographs, ${ }^{113}$ newspapers ${ }^{114}$ and diary entries ${ }^{115}$ of German military men. This variety of sources goes towards proper engagement with history by allowing conclusions to be drawn from a range of primary sources, not just from one type of source. The cited sources also complement the role of individual actors and their significance in history. For instance, the photograph of Lieutenant General Lothar von Trotha all decked out in his German military regalia evokes an emotional response in the reader and it matches some of the criticism of von Trotha as someone who was unable to go beyond the military mindset. ${ }^{116}$ The sources also illustrate the reality of institutional violence, a sociological concept that is a recurring motif in the text. This can be seen in the diary entry of Captain Viktor Franke, describing a "customary military practice: executing the wounded", where an unsuspecting wounded Herero is shot in the back after routine questioning. ${ }^{117}$ Professor Hull

108 At 324 (emphasis added).

109 At 324 (emphasis added).

110 Turner, above n 104, at 395.

111 Hull, above n 100 , at 3-4.

112 At 9.

113 At 23-24.

114 At 18.

115 At 20 .

116 At 24.

117 At 20. 
complements this diary entry with a brief personal summary of Captain Franke, describing him as "[d]eeply religious, free-thinking, practical, and hypersensitive"118 and noting that he "was horrified by [this] gratuitous brutality.". ${ }^{119}$ Professor Hull comments that Captain Franke's personal nature, in particular, his disgust for this practice, put him among a select few who treated the Herero more equitably. ${ }^{120}$

Professor Hull's work thus provides a toolkit of practical approaches to circumvent the formalist tendencies of disciplines, such as international law. It goes beyond international legal jargon towards a more humanistic understanding of events. In doing so, she also challenges the disciplinary boundaries of the historical discipline to frame her argument in a way that captures the nuance of the Namibian genocide. Equally, she does not move to completely abandon her discipline. She uses aspects of her discipline which she believes allow for greater empathy and a holistic perspective. She achieves this using a wide range of primary materials, including the diaries of Prussian foot soldiers.

\section{Marilyn Lake and Henry Reynolds on the Japanese proposal to end racial discrimination in the League of Nations}

A proper engagement with the history of international law answers the question: what has the history of international law got to do with the current world? The inescapable result will be the following question: is one's country implicated in blocking early moves to advance the human rights of non-Europeans on the international stage? Formalist histories of international law cannot answer these questions adequately and thus investigation into the history discipline as exemplified by the work of Professors Marilyn Lake and Henry Reynolds illustrates a possible way to respond to these salient questions. Marilyn Lake is the Charles La Trobe Professor of History at La Trobe University ${ }^{121}$ and Henry Reynolds is a Professorial Fellow in history at the University of Tasmania. ${ }^{122}$ Their work on the Japanese proposal for racial equality in the League of Nations covenant provides an illuminating example of the necessity of interdisciplinary investigations in properly engaging with the history of international law. ${ }^{123}$

There are two key reasons for this. First, it goes beyond the formalist impulse of exploring aspects of history that make it onto the text of the League of Nations covenant and its associated travaux préparatoires. Formalist reasoning dictates that anything not in the covenant is not international law and therefore not worth considering. Formalism is based on the legal method. The legal method is apt

118 At 20 .

119 At 20

120 At 20.

121 "Prof Marilyn Lake" (2016) University of Melbourne <www.findanexpert.unimelb.edu.au>.

122 "Henry Reynolds" (2006) University of Tasmania <www.utas.edu.au>.

123 Lake and Reynolds, above n 80, at 284-309. 
for legal problem-solving. However, in exploring the history of international law there is no rational reason to be bound by the international legal method. History is a strange beast. It is not necessarily explained by legal concepts and legal precedents or instruments of law. It explores the context of international law that is.

Secondly, it goes beyond the state-centric lens of formalist histories of international law to consider the role of individuals. Formalist histories centralise state actors in historical accounts of international law. Yet, individual actors do have the capacity to shape history; historical accounts should not exclude them arbitrarily just because they are not state actors. After all, states are made of up individuals. Histories should centralise people as opposed to states. This is necessary if international law is live up to its heroic self-concept: an international law for all. The work of Professors Lake and Reynolds explores the main actors who were key negotiators and those with a more peripheral role in the Japanese proposal for racial equality at the League of Nations. These individual actors include President Woodrow Wilson and his advisor Colonel Edward Mandell House; Japanese delegates Marquis Saionji, Viscount Chinda Sutemi, Baron Makino Nobuaki, and Prince Konoe Fumimaro; Australian Prime Minister W M Hughes; the German Kaiser; Lord Robert Cecil; Arthur Balfour; William F Massey from New Zealand; and Jan Smuts from South Africa. ${ }^{124}$ By considering the various roles of these individual actors, Lake and Reynolds seek to provide a more holistic perspective.

In its examination of the key actors, the work effectively counters grand narratives that might otherwise become dominant. The analysis of President Wilson's role is particularly noteworthy. The work explores the reasons for "Wilson's ambivalence"125 on the Japanese proposal, drawing on the wider background of his life beyond his work in the Paris Peace Conference. First, it notes his Southern upbringing and suggests that "... there is a little doubt he remained a Southerner in his attitude to race relations". ${ }^{126}$ Secondly, it looks at Wilson's role as President of Princeton University in supporting segregation by barring Black students from enrolling. ${ }^{127}$ Thirdly, it looks at how he was perceived during his Presidency of the United States, with disapproving critique from contemporary Black leaders, such as Booker T Washington on Wilson's record in promoting segregation in his administration and his support of the film The Birth of a Nation (associated with the Ku Klux Klan in its racist portrayal of Black people). ${ }^{128}$ Finally, it notes that the most important reason for Wilson's opposition to Japan's proposal was his vested interest in maintaining political power in California, where electioneering based on anti-Japanese sentiments became popular among the voting public who

124 At $285-301$.

125 At 292

126 At 292

127 At 292

128 At 292. 
saw immigrants as a threat. ${ }^{129}$ This anti-immigration platform had already been of service to Wilson in his winning presidential campaigns in 1912 and $1916 .{ }^{130}$ In 1918 , however, Wilson was bitterly defeated by Henry Cabot Lodge who campaigned strongly against Japanese immigration and became Senate Majority Leader and Chair of the Foreign Relations Committee during midterm Congressional elections of that year. ${ }^{131} \mathrm{~A}$ lot was hanging in the balance for Wilson and regarding Japan's proposal, he could not be seen to be anything but strongly anti-immigration. ${ }^{132}$

Equally, Professors Lake and Reynolds' portrayal of the then Australian Prime Minister W M Hughes is particularly insightful. The various sources utilised (again demonstrating proper engagement) provide critical insight into Hughes. The diary entry of American Colonel Stephen Bonsal indicates how Hughes harangued Lloyd George about preventing the racial equality proposal from being recognised in any part of the covenant. ${ }^{133}$ It also cites a telegram between Hughes and WA Watt, the then Australian Deputy Prime Minister, confirming that any racial equality provision would be rejected by the Australian people and the wider Government. ${ }^{134}$ Further cable conversations between Watt and Hughes show Hughes worried that the White Australia policy could be compromised. ${ }^{135}$ At the end of the conference, Professors Lake and Reynolds conclude that "[i]n Australia, Prime Minister Hughes, one of the leading proselytisers of whiteness, was basking in his triumph." ${ }^{136}$ Among the more peripheral actors, the example of American Colonel Edward Mandel House is important. The authors assert that he was "... an admirer of Australian democracy", ${ }^{137}$ that his political predilections reflected that of the Australian Government and that "[h]is support of the Australian position at Versailles would be crucial in the defeat of the Japanese bid for racial equality". ${ }^{138}$ Equally, Professors Lake and Reynolds use a translated biography of Prince Konoe Fumimaro, who was an influential aristocrat, to discuss his role in championing the Japanese impetus on racial equality at the Paris Conference (including through the writing of articles). This was based

129 At 292.

130 At 292.

131 At 292.

132 At 292 .

133 At $293-294$

134 At 294.

135 At 294.

136 At 308

137 At 289.

138 At 289. 
on a nationalistic sentiment that the Japanese must set bottom lines for their dealings with the West, including the eradication of discrimination against people of Asian descent. ${ }^{139}$

Proper engagement entails going beyond Eurocentric narratives to provide uncensored work that highlights the big picture while being mindful of issues of justice and the rights of minority groups. By engaging with individual actors in this way, Professor Lake and Professor Reynolds shed light on the role of various state leaders in defeating the racial equality provision. This has particular importance for countries like Australia who are now suffering a similar crisis of conscience in their offshore detention of so-called asylum seekers. ${ }^{140}$ If not for the focus on diplomatic actors, the conceptual link between the relevance of the racial equality proposal and modern race relations will remain hidden from the official record.

\section{E Political Science}

\section{Susan Buck-Morss and "Hegel and Haiti"}

Susan Buck-Morss is a Professor of Political Philosophy and Social Theory at the Department of Government, Cornell University. ${ }^{141}$ Professor Buck-Morss' work on "Hegel and Haiti" ${ }^{142}$ is a particularly helpful example to consider. This work and its methodology are of utmost importance to properly engage with the history of international law, particularly about slavery and the abolition of slavery. A central element of the work's genius is in its clear penchant for interdisciplinary investigations. Professor Buck-Morss outlines the concerns arising from formalist approaches to history as follows: ${ }^{143}$

When national histories are conceived as self-contained, or when the separate aspects of history are treated in disciplinary isolation, counterevidence is pushed to the margins as irrelevant. The greater the specialization of knowledge, the more advanced the level of research, the longer and more venerable the scholarly tradition, the easier it is to ignore discordant facts.

Professor Buck-Morss' work highlights the necessity of undertaking interdisciplinary investigations not only for international lawyers and historians, but also for political scientists. The tendency to use disciplinary bounds to exclude inconvenient or unwelcome counter-evidence is

139 At 288; and see also Yoshitake Oke Konoe Fumimaro: A Political Biography (Shumpei Okamoto and Partricia Murray (translators), University of Tokyo Press, Tokyo, 1972).

140 See generally Ben Saul "Dark Justice: Australia's Indefinite Detention of Refugees on Security Grounds under International Human Rights Law" (2012) 13(2) Melb J Int Law 685 at 685-731.

141 Buck-Morss, above n 1, at 822.

142 At 821

143 At 822 . 
brought to life in her critique of historian Professor Schama's The Embarrassment of Riches. ${ }^{144}$ Despite Professor Schama's work on the Dutch Golden Age being described as "a model in the field of cultural history" 145 by his peers, Professor Buck-Morss finds that "topics of slavery, the slave trade, and slave labor are never discussed". ${ }^{146}$ She asserts that Professor Schama's work neglects the contribution of the dominant Dutch position in the slave trade to the wealth of the Dutch state. Even though Professor Schama's work mentions Dutch attempts to break through slavery, it is only a metaphor. It applies only the Dutch repudiation of Spanish control of their lands, not to the slavery of Africans. ${ }^{147}$ One of the unique aspects of Professor Buck-Morss' approach is her use of art history. In particular, she includes a Dutch painting from 1648 named Portrait of a Dutch Family by Franz Hals which depicts a black boy who is assumed to be a slave. ${ }^{148}$ Although a look into Professor Schama's work shows a clear grounding in discussions of art history, ${ }^{149}$ it nonetheless omits the discussion of art that depicts black slaves. In the words of Professor Buck-Morss: ${ }^{150}$

Of course, given the absence of slaves from Schama's written account, they would have been out of place

in the illustrations. The consequence of this scholarship is partial blindness among seas of perspicacity,

and it is characteristic of Western academic scholarship, as we shall see.

For conventional international lawyers, 1648 is an auspicious year that is associated with the birth of international law; yet as in Franz Hals' portrait, slaves stand in a kind of timeless fashion where unbeknown to and excluding them, a grand universalist system of law is at birth. ${ }^{151}$ In discussing the work of great theorists of this time, such as John Locke in his Two Treatises of Government (1690), ${ }^{152}$ Professor Buck-Morss reveals a continual motif where "slavery was a metaphor for legal tyranny, as it was used generally in British parliamentary debates on constitutional theory." ${ }^{153}$ She is equally

144 Simon Schama The Embarrassment of Riches: An Interpretation of Dutch Culture in the Golden Age (Vintage Books, New York, 1987).

145 Buck-Morss, above n 1, at 823 .

146 At 823 .

147 At 823 .

148 At $824-825$.

149 Schama, above n 144, at 10.

150 Buck-Morss, above n 1, at 825 .

151 See generally Benno Teschke The Myth of 1648: Class, Geopolitics and the Making of Modern International relations (Verso, London, 2003).

152 See John Locke Two Treatises of Government: A Critical Edition with an Introduction and Apparatus Criticus (Peter Laslett (ed), Cambridge University Press, Cambridge, 1960) at 141.

153 Buck-Morss, above n 1, at 826. 
critical of Jean-Jacques Rousseau in his work On the Social Contract. ${ }^{154}$ Professor Buck-Morss notes that based on Rousseau's writings, slavery is something that would cause great offence to his intellect and moral compass. Despite this, Rousseau, a leading figure in the French Revolution, "represses from consciousness the millions of really existing, European-owned slaves, as he relentlessly condemns the institution." 155

One of the strengths of her work is her connection of history with the wider political context. Although Professor Buck-Morss does not specifically apply it to Rousseau's position, she discusses Le Code Noir, a corpus of French law that legalised slavery in the French colonies and set out punishments for runaway slaves. ${ }^{156}$ This is particularly important given that France's economic wealth at the time was dependent on sugar production in its colonies, which in turn led to a substantial increase in the demand for slaves. ${ }^{157}$ Interestingly, she notes that one-fifth of the French middle class at the time had a financial stake in the slave economy. ${ }^{158}$

The discussion of Locke and Rousseau dovetails nicely with Professor Buck-Morss' most profound finding that: ${ }^{159}$

The Haitian Revolution was the crucible, the trial by fire for the ideals of the French Enlightenment. And every European who was part of the bourgeois reading public knew it.

Crucially, Professor Buck-Morss asks: ${ }^{160}$

Why is ending the silence on Hegel and Haiti important? Given Hegel's ultimate concession to slavery's continuance - moreover, given the fact that Hegel's philosophy of history has provided for two centuries a justification for the most complacent forms of Eurocentrism (Hegel was perhaps always a cultural racist if not a biological one) - why is it of more than arcane interest to retrieve from oblivion this fragment of history, the truth of which has managed to slip away from us?

154 See Jean-Jacques Rousseau "On the Social Contract" in Donald A Cress (ed and translator) The Basic Political Writings (Hackett Publishing, Indianapolis, 1988) 153.

155 Buck-Morss, above n 1, at 830 .

156 At 830

157 At 827; and see also Sidney W Mintz Sweetness and Power: The Place of Sugar in Modern History (Viking Press, New York, 1985).

158 Buck-Morss, above n 1, at 827-828; and see also Louis Sala-Molins Le Code Noir, ou, Le calvaire de Canaan (Presses universitaires de France, Paris, 1987) at 244.

159 Buck-Morss, above n 1, at 837.

160 At 864 . 
She ventures to question whether "... Hegel's understanding of politics was modern". ${ }^{161}$ She answers in the affirmative and contends that The Phenomenology of the Spirit was actually about the Haitian revolution. ${ }^{162}$ Yet she laments that the Hegel scholars have not conveyed this. ${ }^{163}$ Her work is unconventional for international lawyers in the sense that it contains artwork and engravings, such as an engraving of the temple to commemorate Haitian independence in $1805 .{ }^{164}$ These sources complement Professor Buck-Morss' conclusion on the biases of Hegel.

She proceeds to explore Hegel, whose writings on lordship and bondage, including The Phenomenology of the Mind, coincided with the timeframe of the Haitian revolution. She questions whether or not Hegel intended to include the Haitian revolution in framing his philosophical theories. ${ }^{165}$ She notes that the Haitian Revolution captured the imagination of continental Europe because it usurped the racial prejudices inherent in the normative order of the time. Even those who did not support the cause of the slaves could see its significance for the perpetuation of Western liberal values. ${ }^{166}$

\section{Timur Kuran and Ottoman capitulations}

Formalist approaches to the history of international law hold that "[w]riters on international law agree that its development in its present form began in the 16th century among the Christian States of Europe". ${ }^{167}$ However, the work of Professor Kuran helps dispel this notion through his scholarship on the "bilateral trade treaties [of the Ottoman Empire] known as capitulations." 168 Timur Kuran is both a Professor of Economics and Political Science and a Professor of Islamic Studies at Duke University. ${ }^{169}$ Thus, his disciplinary background encompasses three disciplines: economics, political science and Islamic studies. His work on the impact of the Ottoman capitulations adds a gloss on the understanding of the necessity of interdisciplinary investigations for the proper engagement with the history of international law. ${ }^{170}$ He shows that these capitulations were not merely an "... ambiguous

\section{At 851 .}

162 At $852-853$.

163 At 852 .

164 At 857.

165 At 842-843; and see also GWF Hegel The Phenomenology of the Mind (Sir JB Baillie (translator), Harper \& Row, New York, 1967).

166 Buck-Morss, above n 1, at 845.

167 Wood, above n 94, at 262.

168 Timur Kuran The Long Divergence: How Islamic Law Held Back the Middle East (Princeton University Press, Princeton, 2011) at 209.

169 "Timur Kuran" (2016) Duke University < www.polisci.duke.edu>.

170 Kuran, above n 168, at 209-227. 
combination of treaties and of compromise between Christian and Turkish practice". ${ }^{171}$ The capitulations were formed by negotiations between emperors of the Ottoman empire and the monarchs of Europe. ${ }^{172}$ The capitulations provided an exemption from local Islamic laws to traders coming from the East and the West. ${ }^{173}$ By the 1900s, the capitulations had the effect of making outside traders and their agents immune from levies, duties and tariffs that would otherwise be imposed on locals. ${ }^{174}$ The capitulations naturally became a burden for both locals and the Ottoman rulers. ${ }^{175}$

Professor Kuran's work contains references to various Islamic concepts which highlight the nature of the capitulations. Professor Kuran notes that capitulations "... limited the reach of Islamic law in Muslim-governed territories." ${ }^{176}$ A key concept of Islamic law relating to non-Muslims that is utilised is the dichotomy between "dār al-Islām [abode of Islam]"177 and "dār al-harb [abode of war]". ${ }^{178}$ Professor Kuran explains this as "Specifically, protections afforded to the residents of Muslimgoverned territories may be denied to non-Muslim foreigners." ${ }^{179}$ However, foreigners who contribute to and are committed to amorous relations can be given special protections under Islamic law. ${ }^{180}$ Professor Kuran argues that "[i]t was legitimate, therefore, to grant privileges to selected Christian nations capable of serving Muslim goals." 181 This provided a theological route and consequently "[t]he earliest capitulations were easily justified on religious grounds." 182 Professor Kuran also refers to Turkish historians, such as Mehmet Genç, to add nuance to the political manoeuvring of Ottoman rulers who sought to shift the balance of power against local traders. ${ }^{183}$

This work is premised on Professor Kuran's expertise in Islamic studies and is corroborated by other scholarship. Professor of Law, David P Fidler, considers "A Kinder, Gentler System of

171 Wood, above n 94, at 272.

172 Kuran, above n 168, at 209.

173 At 209.

174 At 209

175 At 209.

176 At 225.

177 At 226 .

178 At 226.

179 At 226

180 At 226 .

181 At 226.

182 At 226

183 At 216. 
Capitulations" 184 in the structural adjustment policies pursued by the World Bank and the International Monetary Fund. ${ }^{185}$ In Professor Fidler's exploration, he does undertake interdisciplinary investigations into the Ottoman capitulations. This helps substantiate his argument about structural adjustment policies. ${ }^{186}$ Although Professor Fidler's work predates Professor Kuran's work by 11 years, it nonetheless foreshadows it. Professor Fidler notes that although the initial development of the capitulations was premised on the pride and whims of the Ottoman Empire, from the late 1100s to the late 1800 s, it became the undoing of the Ottoman Empire. ${ }^{187}$

It is no wonder, then, that cheer spread across the Ottoman Empire as it entered World War One that represented freedom from the shackles of the restraints imposed by the capitulations. ${ }^{188}$ In effect, Professor Fidler foreshadowed how Professor Kuran's work can help to augment an understanding of the colonial dichotomy between so-called civilised and uncivilised nations, which frames the history of international law. ${ }^{189}$ The work of Jeremy Waldron, Professor of Law, on ius gentium also foreshadows the tensions outlined in Professor Kuran's work. ${ }^{190}$ There is a parallel between the nature of the formation of capitulations in the Ottoman Empire and the gloss that Professor Waldron adds on ius gentium. Professor Waldron explains Roman law developed ius gentium as a framework to protect the rights of outsiders in Roman territory and therefore Roman jurists saw ius gentium as the "law common to all nations", which was the inverse of ius civile, to which all Roman citizens were subject. ${ }^{191}$

There is no denying the negative impact of the capitulations on the Ottoman people. Yet, it parallels the Roman body of ius gentium. This illustrates that the international law discipline with its formalist impulses has neglected to give capitulations its due reverence. In the same year that Professor Kuran's work was published, Professor of Mediterranean History at the University of Cambridge, David Abulafia, published a 783-page book - and somewhat grandly titled - The Great Sea: A Human History of the Mediterranean. ${ }^{192}$ However, only one page of this work even mentions

184 David P Fidler "A Kinder, Gentler System of Capitulations? International Law, Structural Adjustment Policies, and the Standard of Liberal, Globalized Civilization" (2000) 35(3) Tex Int'l L J 387 at 387.

185 At 388

186 At 390

187 At 390

188 Kuran, above n 170, at 209.

189 Fidler, above n 184, at 392; and see also Gerrit W Gong The Standard of 'Civilization' in International Society (Clarendon Press, Oxford, 1984).

190 Jeremy Waldron "Foreign Law and the Modern Ius Gentium" (2005) 119(1) Harv L Rev 129.

191 At 133 .

192 David Abulafia The Great Sea: A Human History of the Mediterranean (Oxford University Press, Oxford, 2011). 
the capitulations, ${ }^{193}$ let alone its interrelationships with concepts of Islamic law. Even though Professor Abulafia is not an international lawyer, his work does demonstrate the indirect censoring that happens when one adheres to the strictures of one's discipline and fails to carry out interdisciplinary investigations. There is scope for concepts from the Islamic Studies discipline, as outlined by Professor Kuran, to be used to convey some of the causal relationships and nuances of the Ottoman capitulations for global trade. A limited narrative of certain capitulations without the interdisciplinary approaches means that proper engagement with the place of capitulations in the history of international law becomes significantly diminished.

\section{F Journalism}

\section{John Pilger and the fate of the Chagos Islanders}

John Pilger is a journalist and part of the Australian diaspora in the United Kingdom. ${ }^{194}$ John Pilger's work on the Chagos Islanders is a testament to why proper engagement with the history of international law makes interdisciplinary investigations vital in fields such as journalism. ${ }^{195}$ For orthodox international lawyers, regarding journalism, as a serious discipline may be a hard pill to swallow. Nevertheless, journalism allows for proper engagement with history, particularly of history that is modern enough to include people who can be interviewed. Journalism allows for creativity, a more holistic understanding and greater empathy with those involved in historical events than perhaps any other discipline. John Pilger's work on the 2,000 people who once lived in a British colony, the Chagos archipelago, supports this notion. ${ }^{196}$ Pilger evokes sentimentality in talking about the archipelago's past, namely "[t]he grainy, flickering images" ${ }^{197}$ of a vibrant community with all the markers of a thriving town such as a hospital, a church, a railway, and a school, set in a tropical paradise. $^{198}$

Pilger juxtaposes this resplendent vision of the past with the stark, cold, present reality of the former residents of the archipelago by including a series of interviews with former islanders and charting their life course and consequences along the way. Pilger outlines the travesty of justice carried out by successive British administrations from both sides of the political divide in the twenty years from 1960, using unscrupulous methods to forcibly remove all of the Chagossians from Diego Garcia so that the island of Diego Garcia (a fruit of the British colonial enterprise) could be sold to

\section{At 422 .}

194 "John Pilger Biography" (2016) John Pilger <www.johnpilger.com>.

195 John Pilger Freedom Next Time (Bantam Press, London, 2006) at 19-60.

196 At 19.

197 At 19.

198 At 19. 
the Americans as a navy base. ${ }^{199}$ These events occurred in the strictest of confidence; not even the British Parliament or the American authorities were aware of the forced removal of the Chagossians. ${ }^{200}$ This human rights violation was not exposed by news media at the time, and often $\mathrm{BBC}$ reporters would refer to the island of Diego Garcia as "uninhabited". ${ }^{201}$

Pilger quips that: ${ }^{202}$

The Chagossians were treated like Australia's Aborigines in the nineteenth century: they were deemed not

to exist. Not only was their homeland stolen from them, they were taken out of history.

The notion of being "taken out of history" 203 is of profound importance to this article's earlier discussions about removing both direct and indirect censorship from the history of international law.

In terms of indirect censorship, it is important to consider the disciplinary impulse to exclude material that is deemed irrelevant. Although John Pilger does not target his comments at the history of international law per se, his sentiments still carry relevance when he outlines a range of complex dynamics. These include obfuscation by United Kingdom government departments such as the Foreign Office to the collective forgetting by Members of Parliament, policymakers and scholars (except Mark Curtis who writes on the dehumanisation of the Chagossians). ${ }^{204}$

One of Pilger's notable interviewees is Rita Bancoult. ${ }^{205}$ The interview is conducted in Rita's home, which adds to the very personal nature of her account and evokes a sense of empathy with the readers. ${ }^{206}$ Rita's account of her life after being moved to Mauritius from Diego Garcia is heartwrenching. Rita states: ${ }^{207}$

When we arrived in Mauritius ... we were not even recognised as human beings. My children had nothing

to eat, so I went from house to house in a good-looking street, I got a domestic's job, but when the lady

found that I was from the Chagos, she sacked me. All I could do was search bins in the street for plastic

bags containing stale bread. In Mauritius, the well-off throw out most of their bread. It would take me all

day to collect a meal of this for the children; it's how we lived.

199 At 21

200 At 21 .

201 At 21

202 At 21 (emphasis added).

203 At 21 .

204 At 21-22.

205 At 28

206 At 29.

207 At 29. 
Pilger complements Rita's account with detail of the death of four of her children, including one from gangrene. ${ }^{208}$ Now the contrast between the past and the present comes to bear.

Pilger does look at some of the procedural aspects of the Chagossian case, including the petition to the British High Commission in Port Louis. ${ }^{209} \mathrm{He}$ also looks at a case brought by the Chagos Islanders in the United Kingdom High Court. ${ }^{210}$ However, his approach is not to get lost in the legal jargon but to centralise the perspectives and concerns of the everyday Chagossians. This is exemplified by the song sung by Pilger's interviewees on his last day in Mauritius:211

When I was living on Diego, I was like a beautiful bird up in the sky. Since I am here, I am living a worthless life. So give me your hand, my friend. We will cry and send our message to the world that the military base is in our ocean. Yes, I have regrets in my heart. Look at my child who is growing - He does not know the native land of his mother. When we seek justice, don't beat us, Mr Policeman ... When I was living on Diego, I was like a beautiful bird up in the sky.

The international law discipline must broaden its scholarship to embrace other disciplines, including journalism, to narrate its histories. Otherwise, the world will not understand the true human cost of certain political actions and a great injustice will continue to be perpetuated.

\section{G International Lawyers who take an Interdisciplinary Approach}

\section{Ileana M Porras on Hugo Grotius}

Professor Ileana M Porras is an Associate Dean at the University of Miami School of Law ${ }^{212}$ and her article on Hugo Grotius provides an example of international legal work that effectively uses interdisciplinary investigations to fully engage with the history of international law. ${ }^{213}$ The work of Professor Porras highlights the importance of scholarship that responds to the complexities in the underpinnings of international law and its so-called founding fathers. In particular, she demonstrates that scholars such as Grotius did not write within the narrow purview of the now well-established discipline that is international law. In fact, his writings became foundational in various disciplinary contexts. Furthermore, she shows how some of the myths relating to the strict separation of fields,

208 At 29.

209 At 30.

210 At $50-60$.

211 At 60 .

212 "Ileana Porras" (2015) University of Miami School of Law <www.law.miami.edu>.

213 Ileana M Porras "Constructing International Law in the East Indian Seas: Property, Sovereignty, Commerce and War in Hugo Grotius' De Iure Praedae - The Law of Prize and Booty, or 'On How to Distinguish Merchants from Pirates'" (2006) 31(3) Brook J Int'l L 741. 
such as public international law and international trade law, are supported by a failure to think outside disciplinary bounds.

She maps Grotius' contribution to the field of international law: ${ }^{214}$

It is a doctrine of the freedom of the seas that supports a defensible right to engage in commerce (already implicit in the theory of justice) and, by claiming the seas as a space outside of state jurisdiction, provides the grounds for private just war between merchants.

This paved the way for "a more expansive and permissive law of war" 215 and cautioned that "commerce became more like war while war became more like commerce." 216 Grotius' work thus became a conduit for greater future conflict "between European merchants in the East Indies".217 Professor Porras' work sought to challenge those "... who have become convinced that the end to war can be achieved through trade liberalization." ${ }^{218}$ She first highlights the interconnected web of literature surrounding Grotius that provides an inherent malleability making interdisciplinary investigations necessary. This malleability is highlighted when she states: ${ }^{219}$

Any foray into the reading of a seventeenth century text such as De Iure Praedae is fraught with peril. It is not just a matter of the ever-present danger of falling into anachronism. The past is indeed a foreign country and we do not speak the language. It is thus almost impossible to read a seventeenth century text in its own terms. We can only guess at the motivations of the actors, and at the association of ideas which colored their understanding of what they were 'up to.'

This malleability is widespread given Grotius' pervasive and enduring legacy apparent in modern disciplines, including: theology, law, political science, philosophy, international relations and history. ${ }^{220}$ Therefore, a proper analysis of Grotius' contribution to the history of international law cannot be done from the perspective of one discipline alone.

Consequently, Professor Porras' work begins to venture into the history discipline to highlight the context of the United Provinces with reference to the work of several historians. ${ }^{221}$ Professor Porras'

214 At 803 .

215 At 803 .

216 At 804 .

217 At 804

218 At 804

219 At 747

220 Porras, above n 213, at 748 .

221 At 748; see also Schama, above n 144; Jonathan Israel Dutch Primacy in World Trade, 1585-1740 (Oxford University Press, Oxford, 1989); Benjamin Schmidt Innocence Abroad: The Dutch Imagination and the New World, 1570-1670 (Cambridge University Press, Cambridge, 2001); Jan de Vries and Adriaan Van Der 
work also shows the necessity to venture into the field of theology, particularly in light of how central theology is to Grotius' argument in De Iure Praedae and other texts such as Prolegomana. ${ }^{222}$ This is accentuated by Grotius' reference to theologians such as Francisco Vitoria in structuring his argument. ${ }^{223}$ In fact, Professor Porras traces Grotius' notion of private war in defence of the right of commerce to "the doctrine of just war". ${ }^{224}$ In particular, this doctrine is ecclesiastical in origin, primarily due to Saint Thomas Aquinas' Summa Theologica. ${ }^{225}$ Grotius' argument essentially "had to contend with Aquinas' three conditions: sovereign authority, just cause, and right intention."226

Proper engagement with the history of international law necessitates interdisciplinary investigations in order to challenge the status quo of what Professor Porras names as "conventional views of international law". 227 These, in Professor Porras' analysis, fail to show the symmetries between so-called "distinct" spheres of international law, namely public international law, which encompasses the laws of war, and international trade law. ${ }^{228}$ This orthodoxy is based on a judgment about war being morally wrong, whereas trade is perceived as being a universal positive. ${ }^{229}$ Yet, war and trade are very much intertwined.

\section{CONCLUSION}

This article has canvassed several nuanced perspectives on how to properly engage with the history of international law. The scholarship of Professor Koskenniemi demonstrates that international lawyers exploring the history of the profession must not adopt a limited self-definition based on reductive binaries which place international law at the forefront of the colonialist mission. Instead, the international law discipline must adopt a self-definition that reflects its complexity. This must include the role of individual actors and sociological phenomena. It must also redefine itself in order to provide reconciliation for those who were previously subjugated under colonisation or who still

Woude The First Modern Economy: Success, Failure, and Perseverance of the Dutch Economy (Cambridge University Press, Cambridge, 1997); and David Armitage The Ideological of Empire in Spain, Britain and France c. 1500-c.1800 (Cambridge University Press, Cambridge, 2000).

222 Porras, above n 213, at 770 .

223 At 771.

224 At 774

225 At 774; and see also Saint Thomas Aquinas The "Summa Theological" of St. Thomas Aquinas (Burns Oates \& Westbourne, London, 1942).

226 Porras, above n 213, at 776 .

227 At 802 .

228 At 802.

229 At 802 . 
live under the intergenerational legacy of colonial acts and policies. There must be an uncensoring of international law histories. This necessitates interdisciplinary investigations.

Equally, the scholarship of Professor Anghie challenges the notion that colonisation was not central to the development of international law. Instead, Anghie shows how colonisation is at the very heart of international law, particularly regarding notions of civilised versus uncivilised peoples. Professor Charlesworth adds a further gloss on the self-definition of international law and how this impacts international law histories. Professor Charlesworth illustrates the international law discipline's obsession with crises. Professor Charlesworth rightly notes the inadequacies of such a conceptual frame. The discipline of international law fails to grasp and respond to the true context of events. These can only be found through interdisciplinary investigations.

Interdisciplinary approaches better showcase the place of structural issues in the episodes of the history of international law. Professor Charlesworth champions the redefinition of international law by attempting to honour the life experiences of marginalised groups through interdisciplinarity. Professor Allott builds on the scholarship of Professors Koskenniemi, Anghie and Charlesworth. He calls for a revolution in the self-definition of the international law discipline. He conceives of an international law that allows the participation of all peoples and all states in the creation of its selfdefinition. This is antithetical to the status quo of international law, determined and led by the biases of the wealthy and powerful in Western, European nations.

Formalism is central to the argument presented in this article. Formalism is very much ingrained in the way international law scholarship currently perpetuates its history, particularly in the way it views its venerable forebears. Professor Koskenniemi has shown the failings of scholarship that embody formalism, especially in relation to histories about Grotius and Emer de Vattel. Professor Koskeniemi's examples also showcase the pervading "state centrism" in international law histories. Formalism is also interconnected with racism and colonialism. Captain Colby's article in the American Journal of International Law (AJIL) "How to Fight Savage Tribes" is one of the most overtly racist articles, filled with colonial biases. It shows how international law theory can be weaponised to suit the purposes of colonialism. Equally, Professor Hugh McKinnon Wood's article in the AJIL exemplifies the myth, often perpetuated by orthodox scholarship, that international law originated in Christian, Western nations. Furthermore, Sir Williams' work on the history of the League of Nations all but ignores the relevance of the Japanese proposal and how interactions between various diplomatic actors brought about its defeat.

This article has highlighted some key examples of interdisciplinary approaches in action. Within the history discipline, the work of Professor Hull allows going beyond black letter international law fact patterns to consider historical sources, such as photographs and diary entries. These sources vividly convey the sociological concepts of violence as they shape the dominant historical narrative. Equally, the work of historians, such as Professors Lake and Reynolds, provides an immense wealth of insights to assist the received wisdom of the international law discipline to re-examine its history. It transcends formalistic scholarship, which focuses on international law covenants and heightens state 
centrism. Instead, the reader is made to return to the lives and actions of diplomatic actors, such as President Wilson and Prime Minister Hughes.

The political science field is also pertinent. Professor Buck-Morss' scholarship utilising interdisciplinary approaches to the philosophy of Hegel is particularly enlightening. She goes beyond the disciplinary boundaries of political philosophy and social theory to which she owes her academic credentials. She also critiques scholars in other disciplines, such as Professor Schama. Thus, she demonstrates that interdisciplinary approaches do not mean accepting the conventional baggage of another discipline. For international lawyers, her work is a Holy Grail in the way it debunks some of the mythologies of international law histories. Equally, Professor Kuran debunks a key Westerncentric myth that international law arose in the Christian West. In fact, if not for the Ottoman capitulations, some of the key frameworks of international law would be non-existent. Yet, the true value of the Ottoman capitulations is seldom honoured in the orthodox formalist international law histories.

The scope for disciplines, such as journalism, to help achieve the revolutionary vision for international law that Professor Allott espouses is immense. The manner in which it allows a direct voice for the downtrodden is unparalleled. Conversely, Professor Porras demonstrates why the history of international law should not be written from the narrow prism of formalist international law. Instead, it is essential, not just meritorious, that findings from other disciplines (such as history) be included in the scholarship. Through interdisciplinarity, Professor Porras shows the links between Grotius' notion of private war in defence of commerce and the "doctrine of just war" in defence of religion.

These insights ultimately coalesce to form one key conclusion: there needs to be a revolution in the treatment of the history of international law. This is because a lack of interdisciplinarity perpetuates the status quo, facilitating a continuation of the formalist narrative. Conversely, the undertaking of interdisciplinary investigations will help empower minority groups who are marginalised by these very same formalist narratives and methodologies. ${ }^{230}$ This line of reasoning is influenced by postmodernist thought in challenging the bounds of history and the identities of its narrators, and in effect seeking to unearth what has been previously concealed. ${ }^{231}$ In particular, scholars have spoken of "epistemic Eurocentrism"232 and some of the examples this article discussed earlier reflect this. Eurocentrism is at the heart of the conception and birth of international law, and so it is no surprise that many international law scholars have devoted their work to exploring the

230 See generally Carole Fink Defending the Rights of Others: The Great Powers, the Jews, and International Minority Protection, 1878-1938 (Cambridge University Press, New York, 2004).

231 RJ Evans In Defence of History (Granta Books, London, 2000) at 191.

232 Alexandra Kemmerer "Towards a Global History of International Law? Editor's Note" (2014) 25 EJIL 287 at 291; and see also RJC Young White Mythologies: Writing History and the West (2nd ed, Routledge, London, 2004). 
relationship between international law and colonialism. ${ }^{233}$ It is fitting to leave the final words to Professor Allott who highlights the widespread disquiet at the status quo, describing it as an: ${ }^{234}$

... outrage made almost unbearable by the complacency of those who operate the international system and the conniving of those who rationalise it, as commentators in public discussion or analysts in an academic context.

The international law discipline must resist obfuscating its colonial histories by using narrow disciplinary rules. Instead, it must heed the calls for a revolution, and utilise interdisciplinary investigations as a vessel for reconciliation and empowerment for those it has previously shunned. Then, international law can truly be an international law for all, not merely an international law for the rich and powerful Christian, Western or European nations, and individuals.

233 Koskenniemi The Gentle Civilizer of Nations: The Rise and Fall of International Law 1870-1960, above n 2, at 9 .

234 The Health of Nations, above n 17, at 399. 
